\title{
ACTUAL USE OF ONLINE STORES: A STUDY OF E-SERVICE QUALITY AND ATTITUDE
}

\author{
Istiqomah Sari Ratih Nur, Insani Amalia Hasta* \\ Department of Accounting, University of Airlangga, Surabaya, Indonesia \\ *E-mail: hastainsani@gmail.com
}

\begin{abstract}
The purpose of this study was to determine the effect of service quality on the determinants of attitudes and actual user on user behavior online store. The research data was obtained from 206 questionnaires distributed by students and the general public in the city of Surabaya, East Java in Indonesia country who had used the services of online stores. The results showed that E-service quality not exhibited significantly influential to actual use. But it is different from the E-service quality significantly influence the attitude which indicates that the service is an important factor for web users online shop. As for Reliability, Responsiveness, Availability, and Privacy show results significant positive effect on E-service quality, it is similar to the attitude that the positive effect on actual use.
\end{abstract}

\section{KEY WORDS}

E-service, quality, attitude, actual use.

For this year followed by increasingly sophisticated information technology has a great influence people's lifestyles. With the internet provides easy access to all kinds of information in the aspects of economy, trading, automotive, and even includes shopping. Public shopping style spending currently following the evolving technology, which was originally expenditure was always met with the seller but now shopping via smartphones certainly be owned by the community that can be accessed anywhere and at any time if you use the internet or WiFi network. Comfort and convenience are offered to the public in Indonesia create an online store is growing rapidly.

The online store is a means of buying and selling is done through the internet by ordering through the website or social media then paid by transfer to the bank account usually provided by online sellers. The online store in Indonesia is not only available on the websites of course even many who use Instagram as a medium to sell his things with display images that can attract public attention. Most seller use Instagram by reason of absence of such binding rules are not required to collect taxes from his goods selling, then do not have to take care of permits and so on.

The attitude has been considered an important factor that determines the use of technology to developing countries, then the behavior and the quality of service is also important for the continuation of the online store. The service company seeks to improve efficiency strategies to provide good and high quality services and that can give satisfaction to customers. According to Oliver et al (2002), E-services are key to the long-term benefits in the digital age, the quality of service is important is the appeal and customer loyalty for the service industry in Indonesia. The quality of service will motivate or push the level of satisfaction and will give effect to a higher usage rate.

The research aims to determine the E-service is quite commonly found in a wide variety of research conducted in a wide range of countries as research samples. However, research on the online store in Indonesia is also not too much. The Research that focus on online web shop in different countries, among others: the purchase of plane tickets through the web in Taiwan (Shu Fang and Tzai Zang, 2011); the use of e-banking in Taiwan (Chien Ta and Wen Chuan, 2010); E-business experience in Greece (Emmanouil and Christos K, 2009); purchase online through web at the University in the United States (Godwin, Kallol, and Peeter, 2010); as well as E-service on the web sports in Australia (Jamie and Aron, 2010). 
The purpose of this research is to know the influence of the determinants of service quality and attitude of the actual user on user behavior online store. The online store that used in this study includes Shopee, Lazada, Tokopedia, bukalapak, and JD.id. The reason researchers use the online shop for researchers surveyed from the highest ranking from the play store which is located at the android and Iphone, apps downloaded from the play store No 5 of the highest order from a wide range of applications online store in Indonesia.

\section{THEORETICAL BACKGROUND AND HYPOTHESIS DEVELOPMENT}

Technology Acceptance Model (TAM). Significant progress this decade able to explain user acceptance of technology supported by the Technology Acceptance Model (TAM). Venkatesh and Davis (2000), A variety of studies using TAM consistently theory to examine the influence of user behavior and intentions of use for better TAM theory digunakan with theory TRA or TPB planning theory. TAM theory explains that the individual behavioral intention to use the system is determined by the confidence and ease of use. Confidence is a person of trust to the system that can improve performance, and ease the user's trust on the use of systems that are not difficult and does not require many efforts. The function of TAM Theory that feeling can affected the easy to use because the easier system can make be more quality.

Diffusion of Innovation (DOI). Lemuria and France (2005), Diffusion of Innovation (DOI) is a more popular models used in information systems approach to explain the adoption of the new technology. DOI is a process in which an innovation communicated through certain channels among all members of the social community. Innovation is the object or idea that still new. The level of innovation diffusion can be influenced by the relative advantage, compatibility, complexity, observability, and trialability. Rogers (1995), scientists found that the relative superiority is the best innovation in the adoption rate of invasion, because of these advantages is able to demonstrate the costs and benefits of adoption. The relative advantages included in the rate of economic profitability, decrease discomfort, low initial cost, Rogers (1995), compatibility is the extent to which innovation is considered consistent with the values, past experience and needs so as to help the individual has a specific meaning to the idea. Innovation can be compatible or not with their beliefs, ideas need to innovate and advance. Furthermore, the complexity of which is the extent to which innovation is considered relatively difficult to do.

E-service Quality (ESQ) and Actual Usage (ACU). In research conducted by Khanifar et al (2012) found that the attributes of the E-service Quality significantly affect the intent of use. This study promotes literature on the relationship between service quality and customer satisfaction and between customer satisfaction and the actual usage of online stores. Therefore, this study propose and test hypotheses as follows:

$\mathrm{H} 1$ : E-service Quality Affects positively Actual Usage of Online Shop.

Factor of E-service Quality (ESQ). Services E-services is a long-term cognitive assessment regarding a high quality and excellence of an organization. Customer-oriented quality essential for companies to encourage customer behavioral intentions continuously (Zhengwei dan Jinkun, 2012). E-service is defined as an interactive service or web-based services that are connected by the Internet, in the service of interaction between the customer and the service provider through advanced technologies such as web sites. According to Godwin, Kallol, and Peeter (2010) defines E-service as a web site that makes it easy for shopping and time efficiency for purchase, as well as an effective delivery. For the webiste today's era not only be opened via a laptop or notebook that will be difficult to carry anywhere because of the larger size and weight, but can use a smartphone that is more practical to carry anywhere. E-service quality can be defined as well as businesses, shows that the deliver through information technology.

According Icek Ajzen (2005) the value comes from the ability of an object that has a significant influence on the individual. The more objects that give a positive goal, the more favorable the desire that affects the object. According to research conducted by Carlos and O'Cass (2010) found that the quality of E-service effect on consumer attitudes in using sports 
web sites. Chu et al, 2012; Pearson et al, 2012; Chang et al, 2009) found that the E-service affects the quality of information, satisfaction and perceived value. This is supported by Chen et al (1999) and Chen et al (2002) found that the three attributes of quality E-services such as erntertainment, informativeness, and the organization can be associated from the website to a positive attitude. Then the online shopping showed that a variety of E-service quality has a positive effect on consumer attitudes on the website (Wolfinbarger and Billy, 2003; Yoo and Donthu, 2001). Grace and O'Cass (2004) found that E-service effect on consumer attitude. Therefore, this study propose and test hypotheses as follows:

H2: E-service Quality Affects Attitude positively Users of Online Shop.

E-service Quality Measurement. According to Parasuraman, Zeithaml and Malhotra (2005) identifies dozens of features on the website level attributes and classifies them into eleven size of e-SQ including reliability, responsiveness, access, flexibility, ease of navigation, efficiency, assurance or confidence, security or privacy, knowledge of price, aesthetics website, and personalization. A study by Yang, Chai and Zhou (2005) developed a quality of service measurement instrument that produces five E-service quality factors, namely usability, website usability, interaction, adequacy of information, and accessibility. The fifth of these factors significantly influence the quality of the overall E-services. This is supported by research from Al Tarawneh (2012) who found that the six dimensions of quality E-services, namely reliability, ease of use, security, responsiveness, personalization.

Reliability in the quality of E-service refers to the technical function of a web, to measure the extent to whether functioning properly or not, then the accurate representation of a product and the accuracy of the order. This is supported by research from Wolfin et al (2003) and Elliot and Speck (2005) who found that reliability has all been found to predict customer attitudes towards online store website. Research Kim et al (2006) found that responsiveness, compensation, privacy, efficiency, system availability, information, graphics style, fulfillment, and contact affects the quality of the E-service. Therefore, this study propose and test hypotheses as follows:

H2a: Reliability / fullfilment positively Affects E-service Quality of Online Shop.

Responsiveness is quick response to the customer to customer orders and make transactions fast. Zeithaml et al (2002) defines responsiveness is timely given the right of a service provider of E-service online store to customers who are transacting online. Eid al (2012) found that responsiveness and dimensions of E-service more positive effect on the quality of E-services. Collier and Bienstock (2006) found that the responsiveness affect the development of the attitude of customers who use online web store. Therefore, this study propose and test hypotheses as follows:

$\mathrm{H} 2 \mathrm{~b}$ : Responsiveness positively Affects E-service Quality of Online Shop.

Hu et al (2012), Availability refers to the technical function of a system. In this context the availability of system availability is described as an online store website that provides the service to purchase goods online customers and provide a smooth process if you want to trade. According to research conducted by Kim et al (2006) found that the availability and nine items of other E-services significantly affect the E-service to the online store website. Therefore, this study propose and test hypotheses as follows:

H2c: System Availability positively affects E-service Quality of Online Shop.

Tamer and Abeer (2010), Privacy is a measure of the extent to which the website is secure and protect all customer privacy information so that no information can be distributed to other online websites. This is supported by research from Wolfin et al (2003) and Elliot and Speck (2005) who found that privacy has all been found to predict a customer's attitude toward online store website. Zeithmal et al (2005) says that privacy is a guarantee of confidentiality of the transaction data such as credit card information, debit card information and protect every individual. Such information can be identified and explored through the internet which is privacy's matter must be addressed as it uncovers customer privacy information for commercial purposes should not happen and it is a determinant of customer trust to the online web store. Therefore, this study propose and test hypotheses as follows:

$\mathrm{H} 2 \mathrm{~d}$. Privacy / Security positively Affects E-service Quality of Online Shop. 
Determinants of Attitude (ATT). According to the theory of diffusion of innovation (DOI) is influenced by the level of diffusion of innovation relative advantage, compatibility, complexity, observatility, and trialability. Relative superiority is the level where innovation considered better than the idea that it replaces. Lemuria and France (2005) relative advantage is the size of the extent to which an innovation is seen ahead of its predecessor, the relative advantage can be measured by profitability. According to research Olatokun and Igbinedion (2009) found that the relative gains significant effect on customer attitudes towards online store website. However this is not supported by research Folorunso et al (2010) which states that the relative advantage not positive effect on attitude of customer on the website of the online store.

Compatibility is a measure of the extent to which innovation looks compatible with the beliefs, experiences, values and needs adopters. Menururt Olatakun research and Igbinedion (2009), and Folorunso et al (2010) found that compatibility significant positive effect on the attitude of the use of online trading technology in Hong Kong.

Then the complexity is defined as critical components that affect the attitude towards the use of information systems or technology. The complexity is similar to the use of TAM that is the extent of the innovation seen by potential adoption because it is relatively difficult to use and difficult to understand. This is supported by research Olatakun and Igbinedion (2009) which states that the complexity significantly affect customer attitudes. However, it is contrary to research Folorunso e al (2010) actually found that complexity does not significantly influence the attitude of the online store website.

Explanation of the above mentioned about various dimensions of attitude. Attitudes can be formed based on trust and the interests (needs) of users are considered in making a decision. A study of Akinyemi et al (2013), Adesiana et al (2010), Ndubisi et al (2006), Jahangir et al (2007), Karlujoto et al (2002), Davis (1989) argues that the attitude of the positive effect on the use of website by users. Therefore, this study propose and test hypotheses as follows:

H3: Attitude Affects positively affects Actual Usage of Online Shop.

Figure 1 below presents the model of this study. This study focuses on examining the influence of the determinants of service quality and attitude of the actual user on user behavior online store.

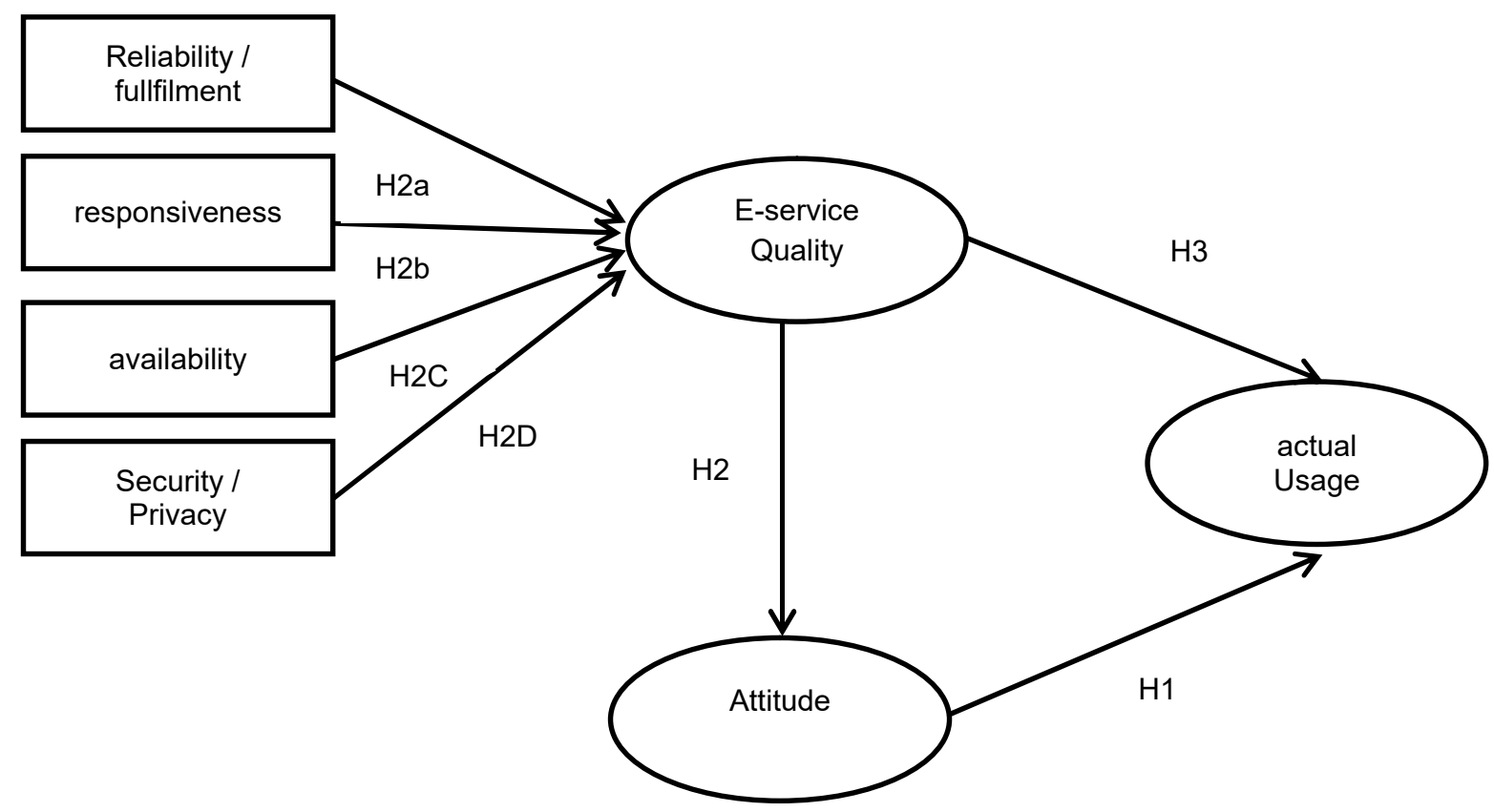

Figure 1 - The proposed Research Model 


\section{METHODS OF RESEARCH}

Population and Sample Research. Data from this study were obtained from questionnaires were distributed and disseminated to students and the general public who live in Surabaya, in Indonesia. Charles et al (2016) study used survey method to test the research model consisting of the following instruments demographic data of respondents, online shop website usage and measurement variables. The survey questions to measure each of the variables were developed from the existing literature that have been tested on previous researchers. On the question of a questionnaire on factors of quality E-service adoption of A.Parasuraman and Valerie A.Zeithaml (2005). Measurement of attitude that comes from Difussion of Theory (DOI), which adopted a research Lemuria and France (2005).

Sampling Procedure and Data Collection. The survey instrument is distributed in the form of a questionnaire with disseminated through google form randomly in Surabaya. The sampling procedure used random sampling, which means the selection of samples taken at random. The analysis technique used is WarpPLS 6.0 for windows that use multi-item scale to measure the research variables are rated on a 5-point Likert scale ranging from 1 is "strongly disagree" to 5 "strongly agree". Data were analyzed using PLS SEM using validity and reliability test for the measurement items. While the outside variable the model using the measured measurement with convergent validity test and discriminant validity.

Instrument Development. In the first part of the questionnaire contains demographic data of respondents, then in the second part contains 32 items of questions to measure all the variables described earlier adopted from previous research and has been modified. This questionnaire distributed in Indonesia since the target respondents in this study is the people of Indonesia.

Operational Definition and Measurement of Variables. Independent Variables. Eservice Quality of five dimensions such as Reliability / fullfilment., Responsiveness, Security / Privacy, Availability. Reliability is the extent to which the promise of these websites send orders and the availability of goods, Responsiveness is how handling problems effectively and go back to the web. Privacy, namely the degree to which this site is secure and able to protect the information of customers, the latter Availability is a technical function right from the web, Attitude is composed of three dimensions including relative advantage, compatibility and complexity. The extent to which the relative advantages are better perceived innovation of ideas. Compatibility is the degree to which innovation is considered consistent with existing values. Then Complexity is the degree to which innovation is considered relatively difficult to use. Dependent Variables. Actual Usage namely the percentage of use of a system by the user.

Demographic profile and Online Shop Usage. Survey respondents in this study is an indivual who never shopped or have ever used an online store website either via smartphone or laptop. Number of questionnaires in the data was 211 respondents, but because there is a questionnaire double charging by the respondents, it is eliminated 5 and the result is 206 valid respondents used for analysis. Charles et al (2016) PLS make for the SmartPLS 3.0 to test the hypothesis to be reflective or formative modeled. PLS is a model of casual maximizing criterion variables of latent variable that can be explained, and SEM-PLS is right method when seen from the nature of the study.

Measurement Model. Reability and Validity tests of the measurement model was measured using a composite reliability, Cronbach's alpha. Average variance extracted, RSquare coefficients, and Adjusted E. Squared coefficients. Mahfud (2013: 65) suggests that the items must have a value of at least, 070 in order to be maintained for subsequent analysis. In this study, there are nine items measuring which has a loading factor of 0.70 below the minimum limit of which (FUL1, FUL4, FUL5, RES4, RES5, AVA1, RA3, CT3, CT4) were excluded from the analysis of the results of the next factor analysis. Recommended AVE value must be greater than 0.5 . All models are consistent with the construction of a 0.7 coefficient $\alpha$ using WarpPLS 6.0. 
Reliability of composite value of the item reliability / fullfilment of 0.891 , amounting to 0.838 Responsiveness, Availability of 8.19 , Security / Privacy amounted to 0.824 , Actual Use of 0.917 , E-service quality by 0.770 , and Attitude of 0,833 . Value composite reliability coefficients of each construct was qualified worth above 0.70 . Thus we can conclude the statements in the questionnaire reliable because the value is more than 0.70 (Hair et al, 2011). This indicates that each item of the questions used to be able to obtain consistent data, which means when the question was asked back will be obtained relatively the same answer to the previous answer.

Validity converging of measurement of each item can be seen from some of the results from the combine output loading, loading patterns and structure loading. When viewed from the outer combine loading the figures indicated more than the maximum value of 0.70 . Discriminative validity was measured using a means of comparing with other constructive.

Table 1 - Correlations among Latent Constructs ( $\varphi$ matrix) with Square root of Aves Hypothesis Test

\begin{tabular}{|c|c|c|c|c|}
\hline hypothesis & Path & path Coefficient & P-Values & significance \\
\hline $\mathrm{H} 1$ & $\mathrm{ESQ} \rightarrow \mathrm{ACU}$ & 0.07 & 0.15 & not Supported \\
\hline $\mathrm{H} 2$ & $\mathrm{ESQ} \rightarrow \mathrm{ATT}$ & 0.66 & $<0.001$ & supported \\
\hline $\mathrm{H} 2 \mathrm{a}$ & $\mathrm{FUL} \rightarrow \mathrm{ESQ}$ & 0.27 & $<0.001$ & supported \\
\hline $\mathrm{H} 2 \mathrm{~b}$ & $\mathrm{RES} \rightarrow \mathrm{ESQ}$ & 0.39 & $<0.001$ & supported \\
\hline $\mathrm{H} 2 \mathrm{C}$ & $\mathrm{AVA} \rightarrow \mathrm{ESQ}$ & 0.35 & $<0.001$ & supported \\
\hline $\mathrm{H} 2 \mathrm{D}$ & $\mathrm{ESQ} \rightarrow \mathrm{PR}$ & 0.39 & $<0.001$ & supported \\
\hline $\mathrm{H} 3$ & $\mathrm{ATT} \rightarrow \mathrm{ACU}$ & 0.62 & supported \\
\hline
\end{tabular}

It can be concluded that E-service quality variables no positive effect on the actual usage of online web store. This can be seen by the $p$-value of 0.15 where the value is greater than 0.05 . Based on the resulting value is the path coefficient of 0.07 . A positive sign in the regression coefficients indicate a direct relationship whereby if the value of E-service quality can provide the better and higher, the actual use on the web shop will also be getting better. It can be concluded that the hypothesis 1 is the variable E-service quality does not affect the actual use.

E-service quality variables significant positive effect on the attitude of web users shop online. It can be seen from the p-value of $<0.001$ and 0.66 coefficient path value. It can be concluded that the hypothesis 2 that E-service quality significant positive effect on attitude. Then variable reliability / fulfillment that significant positive effect on E-service quality. It can be seen based on the value of the $p$-value of $<0.001$ and 0.27 coefficient path value. hypotheses 3can be concluded that significant positive effect on the reliability of E-service quality. For further variable would be equal to a variable interpretation already described.

Structural Equation Model Results:

Hypothesis 1 represent that E-service quality no positive effect on actual use. The results of this study prove that web services quality do not affect the actual use online web store. That's because the quality of service is something that is felt by the user when using the web shop, if users feel comfortable, can feel save to share personal information, find the information needs can be obtained from the web store that will influence the attitudes and web user loyalty. This contrasts with research by Khanifar et al (2012) who found that the attributes of the E-service quality significantly affect the intent of use.

Hypothesis 2 represents that E-service quality significant positive effect on attitude. The results of this study prove that the quality of web services significantly affect the attitude of web users shop online. This is because the quality of services provided by an online web store is an important factor which web users give a good response and have the desire to use the web as much as possible to make transactions. If the web service is an online store that provides a good quality then the customer's attitude will always good and interested in using the online web store.

This is supported by Carlos and O-cass (2010) found that the quality of E-service effect on consumer attitudes on the web, sports content in Australia, meaning that sports lovers more developed and find it more advantageous to use a content site where they feel web sports the better provide E-services of high quality. This study is in line with Chu et al, 2012; 
Pearson et al, 2012; Chang et al, 2009) found that the E-service affects the quality of information, satisfaction and perceived value. Chen et al (1999) and Chen et al (2002) found that the E-service also affect customer attitudes. Likewise applies to (Wolfinbarger and Billy, 2003; Yoo and Donthu, 2001) which says that the quality of online shopping services positively affects consumer attitudes.

Hypothesis $2 a$ represent that reliability significant impact on E-service quality. This proves that the reliability affects the quality of service. This is because the reliability itself is a way to measure the extent to which the web can function properly and the accuracy of a booking. If the reliability of an online web store can provide the accuracy of the order, send the goods on time as promised then web users will find that the quality of online store web service was good. And when a user orders in accordance with what is offered on the web page, the frequency online shop users to shop online or use the web will be more frequent and can be regular because they feel that kualiats that are suitable to their expectations.

This is supported by research Yang, Chai and Zhou (2005) who found that affect the reliability of E-service quality. Al Tarawneh(2012); Wolfin et al (2003) also found that significantly influence the reliability of E-service quality. Elliot and Speck (2005) examines the five factors of E-service, among whom reliability that influence E-service quality using the scenario of online shopping in student marketing, and the result means that the online seller must emphasize factor of sites that fit the profile of engagement / their online web user experience. Then the study of $\mathrm{Kim}$ et al (2006) also states that significantly influence the reliability of E-service quality.

Hypothesis $2 b$ states that responsiveness significant positive effect on E-service quality. This proves that the responsiveness affect the quality of service. This is because the responsiveness rapid response and provide transaction services quickly. Web shop online usually gives users a grace period for transferring nominal price in goods it sends, if the delivery of the goods quickly and well received by the user with the user will find the web service is able to transact quickly. Or if there are transactions of goods that cannot be processed and web online stores provide a response or notification to the user to reprocess the users feel that they are served by the web shop online quickly and well, unconsciously it could make them feel comfortable using the web online store ,

This Research backed by Al tarawneh (2012) which says that the responsiveness and dimensions of E-service more positive effect on E-service quality. Collier and Bienstock (2006) found that the responsiveness affect the development of the attitude of customers who use online web store. This study includes not only E-service on the website but also test the quality of results and recovery of quality so that research is more developed.

Hypothesis 2c states that the availability of significant positive effect on E-service quality. This is because the availability refers to the technical function of a web system. When users access a web-shop online they will assess the convenience, service, and speed of access, if the availability of web online store can be accessed quickly, do not often experience interference or error, and when the transaction goes well, the user feels that the web store online goes according to technical and that the quality of services provided including web view online stores and attractive to users.

This researcher is in line with Kim et al (2006) found that the availability and nine items of other E-services significantly affect the E-service to the online store website. Availability provides a strong influence on the evaluation of the quality of web services online stores. With a more diverse how good the online store's web browser accommodate functions as if it could not make users and online retailers are desperate and it can minimize the loss of browser incompatibilities due to E-service quality web users.

Hypothesis $2 d$ represent that the positive effect on the privacy of E-service quality. This is because the privacy measures the extent to which the web can store users' personal information. Sometimes many users are still afraid because of personal information can be accessed by other online web store or any other person who may abuse it. Jika privacy online web store can be guaranteed and does not make the user feel scared then the user will feel safe if they have to share personal information to the web such as a credit card or debit card. Users will think that shopping online can also guarantee that the personal 
information that describes the quality of service provided is very high because it ensures that person's information cannot be accessed by others.

This research was supported by the Wolfin et al (2003) and Elliot and Speck (2005) have all found privacy to predict a customer's attitude toward online store website. It is also in line with the study of Kim et al (2006) which states that the privacy greatly affect the quality of web services. Often, online retailers using security certification, and the terms of use of information that can improve the user initiative to share personal information. Most online retailers provide information about the privacy and security policies, but tend to forget to promote or advertise by exposing the security certification; if it is done it will slightly reduce the user's worries.

Hypothesis 3 represent that the attitude positive effect onactual use. Attitude in this study using three dimensional models such measurements relative advantage, compatibility and complexity. If the web user was a web shop that is in conformity with the way he shopped, susia his lifestyle to transact online, and users find it easier to gather information on the web is the attitude displayed by the user is able to demonstrate the quality of service can meet all kinds of needs the user is required. This is supported by (Olatokun and Igbinedion (2009); Folorunso et al (2010)) which states attitude affect actual users use

A study of Akinyemi et al (2013), Adesiana et al (2010), Ndubisi et al (2006), Jahangir et al (2007), Karlujoto et al (2002), Davis (1989) argues that the attitude of the positive effect on the use of website by users.

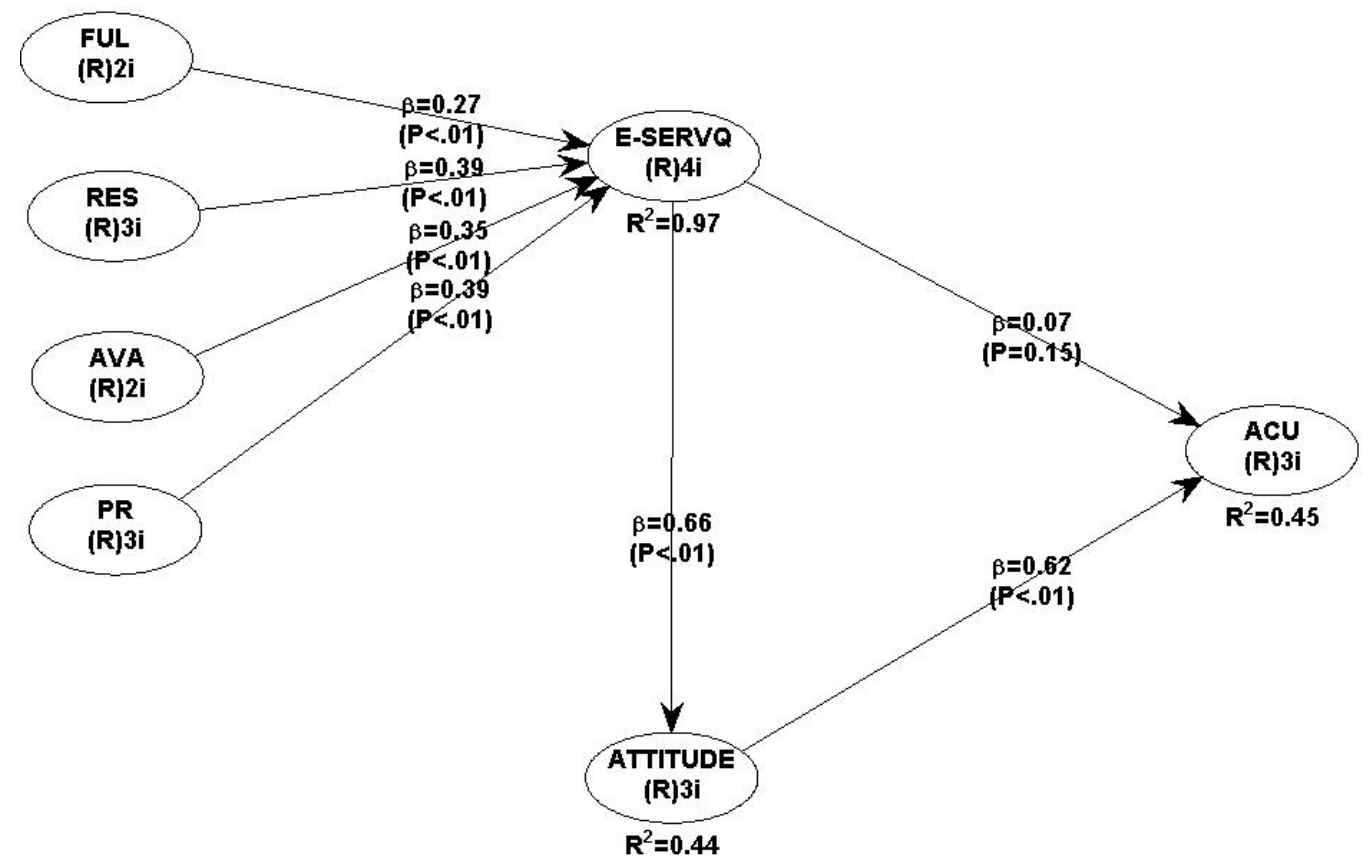

Figure 2 - Model of Online Shop Users with Coefficien of Significant Paths

\section{DISCUSSION OF RESULTS}

This study whether quality of service can affect the determinants of attitudes and actual use online web store. In particular the four dimensions of E-service quality (reliability, responsiveness, availability, privacy) significant positive influence on the quality of services provided by the online store website as Shopee, Lazada, Tokopedia, bukalapak, and jd.id. Can be seen in Figure 3 that the online web store frequented by respondents is $55.3 \%$ Shopee, users feel attracted to what is offered web online store and assume web it has a good quality service. We know that Shopee provide free shipping on promotion for each delivery of goods purchased by the user. 


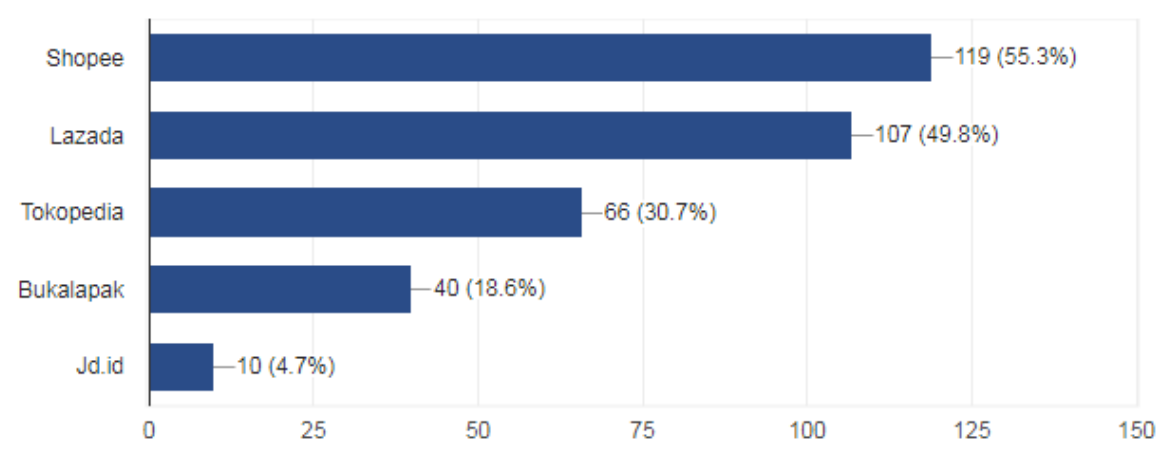

Figure 3 - Percentage of Online Shop frequently used by respondents

The quality of service is very important and always rated by users. People in today's smarter to choose what is more applications keep costs down and be more practical, but it is also based on the consideration of various aspects that make the user feel safe and trust. User confidence could be built through how secure your privacy policy which can protect user information, the user will think if the website can send goods according to the given timeframe and stuff it in accordance with what is shown not it drawn web. All aspects that can affect the attitudes and actual use so that when users access the web, they will find shopping more fun and efficiency time if you use online web store and it will become routine and habits of users.

Otherwise it will create challenge for online store web owners must provide the features and web interface are packaged as attractive as possible in order to attract users, as well as promotions that can be given will also make web users interested. It was not separated from the good quality of services provided and make users embed mindset in their mind that if they want to shop then they will go directly to the online store's web. It can be supported by easy access to the web without being subject to interference and buffering. Their website online store is able to provide all sorts of information on the needs required by society without coming directly into the store.

\section{CONSLUSION}

The purpose of this study was to determine the effect of service quality on the determinants of attitudes and actual user on user behavior online store. The research data was obtained from 206 questionnaires distributed by students and the general public in the city of Surabaya, East Java in Indonesia country who had used the services of online stores such as Shopee, Lazada, Tokopedia, bukalapak, and Jd.id that there are several criteria. This study uses a quantitative method with primary data obtained from questionnaires. This study uses WarpPLS 6.0 using Validity and Reliability tests for measurements models. The results in this study that E-service quality does not affect the actual use, but significant positive effect on attitude. Then the four dimensions of E-services such as reliability, responsiveness, availability, and privacy significant positive effect on E-service quality. Variable attitude which uses three dimensional measurement (relative advantage, compatibility, complexity) significant positive effect on actual use.

The study had several limitations. First, assess the immediate impact of attitude, and service quality test website online store without the intention also to use online web store. This is because the demographic data is not given an option that never use these web sites or not. So all respondents who have ever shopped via online and that can not be filled out the questionnaire this. Second, the study results could be affected by other demographic data related to the study sample. $65.6 \%$ is the number of respondents who have not worked, the rest $34.4 \%$ is the respondents who are already working. And is dominated by scholars of $70.7 \%$. Supposedly more refined research object with a scope. Web users shop online more dominated by people who have not worked and aged between 15-20 years, not too specific. Researchers further need to examine the additional variables: user intent and behavioral 
intention in two online web store just to be more specific for example in Lazada and Shopee, so researchers could compare the respondents more interested in using Lazada or Shopee to buy an item. Future studies need to list the amount of income earned if the respondent has been working and has not worked in order to see the range of income how much more frequently shop online. Researchers can compare the respondents more interested in using Lazada or Shopee to buy an item. Future studies need to list the amount of income earned if the respondent has been working and has not worked in order to see the range of income how much more frequently shop online. Researchers can compare the respondents more interested in using Lazada or Shopee to buy an item. Future studies need to list the amount of income earned if the respondent has been working and has not worked in order to see the range of income how much more frequently shop online.

\section{REFERENCES}

1. Adesina A., Ayo C.K. (2010), "An Empirical Investigation of the Level of User's Acceptance of E-Banking in Nigeria", Journal of Internet banking and Commerce, April 2010, Vol. 15, No. 1.

2. Akinyemi, I. O., Asani, E. O., Adigun, A. A. (2013), "An Investigation of Users' Acceptance

3. and Satisfaction of E-Banking System as a Panacea towards a Cashless Economy in Nigeria". Journal of Emerging Trends in Computing and Information Sciences, Vol. 4, No.12

4. Al-Tarawneh (2012), "Measuring E-service quality from the customers' perspective: an empirical study on banking services", International Research Journal of Finance and Economics. Issue 91, ISSN 1450-2887.

5. Chang, H. H., Wang, Y. and Yanga, W. (2009), "The impact of E-service quality, customer satisfaction and loyalty on e-marketing: Moderating effect of perceived value", Total Quality Management Vol. 20, No. 4, pp. 423-443.

6. Charles K. Ayo. A.A,. Oni O J., Adewoye., Ibukun O.E. (2016). E-banking user's berhaviour E-service quality, attitude, adn customer satisfaction. International Journal of Bank Marketing, Vol. 34 Iss 3.

7. Chen, Q. and Wells, W. (1999), "Attitude toward the site", Journal of Advertising Research, Vol. 39 No. 5, pp. 27-37.

8. Chen, L., Gillenson, M. I., and Sherrell, D. L. (2002), "Enticing online consumers: An extended technology acceptance perspective", Information \& Management, Vol. 39, No. 8, pp. $705-719$.

9. Chien T.B,. Wen C.L. (2010). Measuring the service quality of internet banking: scale development and validation. European Business Review, Vol.22 No.1,pp. 5-24.

10. Chu, P., Lee, G., Chao, C.H. (2012), "Service quality, customer satisfaction, customer trust, and loyalty in an e-banking context”, Social Behavior and Personality, Vol. 40 No. 8, pp. 1271-1284.

11. Collier, J. and Bienstock, C. (2006), "Measuring servicequality in e-retailing", Journal of Service Research, Vol. 8 No. 3, pp. 260-275.

12. Davis F. D. (1989), "Perceived usefulness, perceived ease of use, and user acceptance of information technology", MIS Quarterly, Vol. 13, no. 3, pp. 318-39.

13. Elliott, M.T. and Speck, P.S. (2005), "Factors that affect attitude toward a retail web site", Journal of Marketing Theory and Practice, Vol. 13 No. 1, pp. 40-51.

14. Emmanouil S,. Christos K.G. (2009). "E-service Quality:comparing the perceptions of providers and customers". Manageing Service Quality: An International Journal, Vol.19 Iss.4, pp. 410-430.

15. Folorunso, O., Vincent, R.O., Adekoya, A.F. and Ogunde, A.O. (2010) "Diffusion of Innovation in Social Networking Sites among University Students", International Journal of Computer Science and Security (IJCSS), Vol. 4, No. 3, pp. 361- 372.

16. Grace, D. and O'Cass, A. (2004), "Exploring consumer experiences with a service brand", Journal of Product \& Brand Management, Vol. 13 No. 4, pp. 257-68. 
17. Godwin J.U,. Kallol K.B., Peeter J.K. (2010). " An assessment of customers E-service quality perception, satisfaction and interntion. International Journal of Information Management, Vol.30, pp. 481-492.

18. Hair, J.F., Black, W.C., Babinand, B.J. and Anderson, R.A. (2010), Multivariate Data Analysis, 7th ed., Upper Saddle River, Prentice Hall, NJ.

19. Hu, Y.,Wang, J. and Hung, L. (2012), "Evaluating microblogging E-service quality using ANP", Journal of Multi-Criteria Decision Analysis, Vol. 19 pp. 89-111

20. Icek Ajzen. 2005. Attitudes, Personality, and Behavior. Second Edition. New York: McGraw-Hill Education.

21. Jahangir N. and Begum N. (2008), "The role of perceived usefulness, perceived ease of use, security and privacy, and customer attitude to engender customer adaptation in the context of electronic banking". African Journal of Business Management, Vol. 2 No. 1, pp. 032-040.

22. Jamie Carlson and Aron O'cass. (2010). "Exploring the relationships between E-service quality, satisfaction, attitudes and behaviours in content-driven E-service web sites. Journal of Services Marketing, Vol.24 No.2, pp. 112-127.

23. Karjaluoto, H., Mattila, M., Pento, T. (2002), "Electronic banking in Finland: consumer beliefs and reactions to a new delivery channel", Journal of Financial Services Marketing, Vol. 6, No. 4, pp. 346-361.

24. Khanifar, H., Molavi, Z., Jandaghi, G.R. and Niya, M.J.M. (2012), "Factors influencing the intendancy of e-banking: an integration of TAM \& TPB with E-service quality". Journal of Applied Sciences Research, Vol. 8, No. 3, pp. 1842-1852.

25. Kim, M., Kim, J.H. and Lennon, S.J. (2006), "Online service attributes available on apparel retail web sites: An ESQUAL approach”, Managing Service Quality, Vol. 16, No. 1, pp. 51-77.

26. Ksp. 2017. Retrived Desember, 4 2017. Daya beli terjaga masyarakat belanja lebih cerdas. http://ksp.go.id/daya-beli-terjaga-masyarakat-belanja-lebih-cerdas/index.html

27. Lemuria C dan France B. 2005. The utilization of e-government services:citizen trust, innovation and acceptance factors. Information Systems Journal, Vol.15, pp. 5-25.

28. Mahfud. J dan Dwi R. 2013. Analisis SEM-PLS dengan WarpPLS 3.0. Yogyakarta:Andi.

29. Ndubisi, N.O., Sinti, Q. (2006), "consumer attitudes, system's characteristics and Internet banking adoption in Malaysia", Management Research News, Vol. 29, No. 1/2, pp. 16-19

30. Olatokun, W.M and Igbinedion, L.J. (2009), "The Adoption of Automatic Teller Machines in Nigeria: An Application of the Theory of Diffusion of Innovation", Issues in Informing Science and Information Technology, Vol. 6, pp. $373-393$.

31. Oliveria, P., Roth, A.V. and Gilland, W. (2002), "Achieving competitive capabilities in eservices", Technology Forecasting \& Social Change, Vol. 69, pp. 721-739.

32. Pearson, A., Tadisina, S. and Griffin, C. (2012), "The role of E-service quality and information quality in creating perceived value: antecedents to web site loyalty". Information SystemsManagement, Vol. 29, pp. 201-215.

33. Rogers, E. M. (1995), Diffusion of Innovations New York: The Free Press, 4th Ed.

34. Shu F.L, Tzai Z.L. (2011),"The influence of trust and usefulness on customer perceptions of E-service quality. Social Behaviour and Personality, Vol. 39 No.6, pp. 825-838.

35. Tamer H.E dan Abeer A.M. (2015). "Customer participation in onlice co-creation experience: the role of E-service quality". Journal of research in interactive marketing, Vol. 9 Iss 4 pp.313-336.

36. Venkatesh, V. and Davis, F. (2000), "A theoretical extension of the technology acceptance model: four longitudinal field studies", Management Science, Vol. 46 No. 2, pp. 186-204

37. Wolfinbarger, M. and Gilly, M.C. (2003), "eTailQ: dimensionalizing, measuring and predicting etail quality", Journal of Retailing, Vol. 79 No. 3, pp. 183-198.

38. Yang, Z., Chai, S. Z. and Zhou, N. (2005), "Development and validation of an instrument to measure user perceived service quality of information presenting web portals". Information and Management, Vol. 42, pp. 575-589 
39. Yoo, B. and Donthu, N. (2001), "Developing a scale to measure perceived quality of an internet shopping site (SITEQUAL)", Quarterly Journal of Electronic Commerce, Vol. 2 No. 1, pp. 31-46.

40. Zeithaml, V.A., Parasuraman, A. and Malhotra, A. (2002), "Service quality delivery through web sites: a critical review of extant knowledge", Journal of the Academy of Marketing Science, Vol. 30 No. 4, pp. 362-375.

41. Zeithaml, V.A., Parasuraman, A. and Malhotra, A. (2005), "E-S-QUAL: a multiple-item scale for assessing electronic service quality", Journal of Service Research, Vol. 7, pp. 213-234.

42. Zengwei M. Jinkun Z. 2012. Evidence on e-banking customer satisfaction in the chna commercial bank sector. Journal of Software, Col.7 No.4, April 2012. 